\title{
The Bright and Fascinating World of the Neuroendocrine Cells
}

\author{
Fausto Sessa • Daniela Furlan • Silvia Uccella • \\ Cristina Riva - Stefano La Rosa
}

Published online: 1 April 2014

(C) Springer Science+Business Media New York 2014

The meeting entitled "The bright and fascinating world of the neuroendocrine cells: birth and growth of the Varese School of Pathology," held on May 3, 2013 at Villa Cagnola Hotel in Gazzada Schianno, Varese, Italy (Fig. 1), was organized to celebrate Prof. Carlo Capella who retired on October 31, 2012 after he had dedicated more than 40 years of his life to pathology practice and investigation. Several of his friends (Fig. 2), who are well-known international experts in neuroendocrine pathology, participated in giving lectures both in reviewing topics of interest in this field and summarizing their scientific results, to many of which he had significantly contributed. Different aspects of neuroendocrine pathology were discussed and presented by the following speakers: Cesare Bordi, Gianni Bussolati, Vincenzo Eusebi, Paul Kleihues, Günter Klöppel, Stefano La Rosa, Giuseppe Pelosi, Juan Rosai, Guido Rindi, Aldo Scarpa, Enrico Solcia, and Jacqueline Trouillas. The high scientific level of the meeting was also emphasized by a warm, friendly, and informal atmosphere. More than 200 people attended the meeting, including medical doctors of the University Hospital of Varese; several

\author{
F. Sessa $\cdot$ D. Furlan $\cdot$ S. Uccella $\cdot$ C. Riva \\ Department of Surgical and Morphological Sciences, University of \\ Insubria, Varese, Italy \\ F. Sessa \\ e-mail: fausto.sessa@uninsubria.it \\ D. Furlan \\ e-mail: daniela.furlan@uninsubria.it \\ S. Uccella \\ e-mail: silvia.uccella@uninsubria.it \\ C. Riva \\ e-mail: cristina.riva@uninsubria.it \\ S. La Rosa $(\bowtie)$ \\ Department of Pathology, Ospedale di Circolo, Viale Borri 57, \\ 21100 Varese, Italy \\ e-mail: stefano.larosa@ospedale.varese.it
}

Italian pathologists, almost all of whom were ex-residents of the Varese School of Pathology; medical students; and the whole staff of the Department of Pathology.

Carlo Capella got his medical degree in 1966 at the University of Pavia, where he spent the early years of his career as a fellow of Prof. Cavallero. At the beginning of 1973, he moved to Varese, where he spent all his career as pathologist, researcher, and teacher. He has been the director of the Unit of Anatomic Pathology of the University Hospital since 1983, and in 1990, he became full professor of anatomic pathology. His pioneering works using electron microscopy and immunohistochemistry gave a great contribution to the characterization and classification of gastroenteropancreatic neuroendocrine cells and related neoplasms. He also actively investigated the prognostic role of clinical, histologic, and immunohistochemical markers in such tumors. His long and significant scientific career is documented by more than 200 papers and several book chapters. Due to his impressive work in neuroendocrine pathology, he was involved as a coauthor in the WHO Blue Book series [1-4] and in the AFIP Atlas of Tumor Pathology of the Pancreas [5]. At the University of Insubria, Prof. Capella served as director of the Schools of Pathology and Oncology. He was also involved in the board of the University Library for several years. He was the Italian representative in the European Council of the Directors of the Schools of Pathology. Carlo Capella is now professor emeritus of anatomic pathology at the University of Insubria, and he is still actively involved in the research projects of our department.

This issue of Endocrine Pathology includes papers regarding most of the lectures presented at the meeting. We would like to thank the editors who have given us the opportunity to publish these contributions. We also want to thank warmly all the speakers who made it possible to have a meeting of such a high scientific level and all the people who participated. 


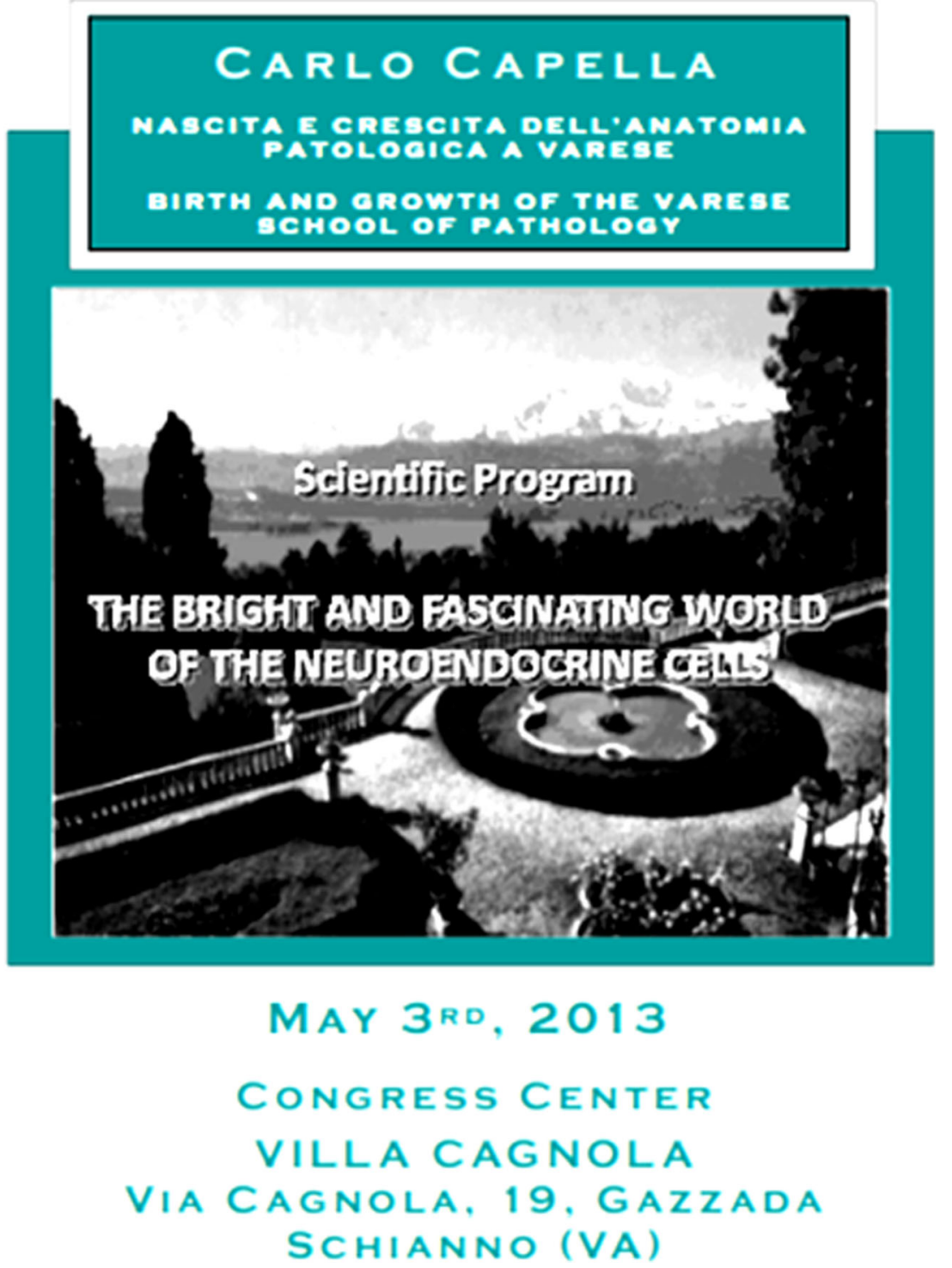

Fig. 1 The meeting entitled "The bright and fascinating world of the neuroendocrine cells: birth and growth of the Varese School of Pathology," organized to celebrate Prof. Carlo Capella's dedication to pathology practice and investigation 


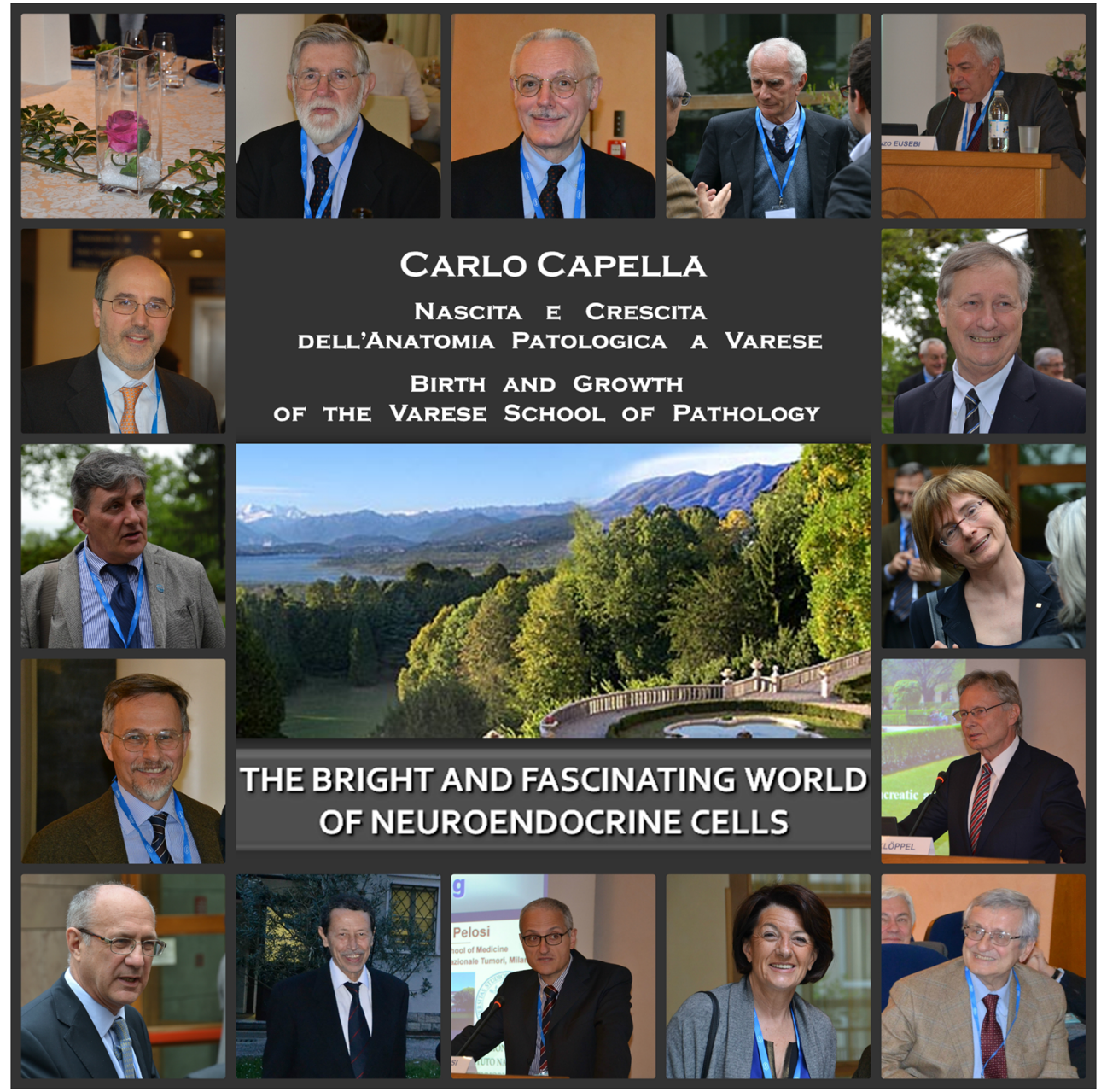

Fig. 2 Prof. Capella's friends who participated in the meeting and gave lectures

\section{References}

1. Solcia E, Klöppel G, Sobin LH, et al. (2000) Histological typing of endocrine tumours. WHO International Histological Classification of Tumours, 2nd Edition. Springer, Berlin

2. Stanley R, Hamilton SR, Aaltonen LA (2000) WHO classification of tumours of the digestive system. IARC Press, Lyon
3. DeLellis RA, Lloyd RV, Heitz PU, Eng C (2004) Pathology \& genetics of tumours of endocrine organs. World Health Organization Classification of Tumours. IARC Press, Lyon

4. Bosman FT, Carneiro F, Hruban RH, Theise ND (2010) WHO classification of tumours of the digestive system. IARC Press, Lyon

5. Solcia E, Capella C, Klöppel G (1997) Atlas of Tumor Pathology. Tumors of the pancreas. AFIP, Washington DC 